\title{
Aggressive Behavior of Children in a Daycare Center ${ }^{1}$
}

\author{
Sidnei Rinaldo Priolo Filho ${ }^{2}$ \\ Universidade Federal de São Carlos, \\ São Carlos-SP, Brazil \\ Nancy Vinagre Fonseca de Almeida \\ Universidade Federal de São Carlos, \\ São Carlos-SP, Brazil
}

\author{
Henrique Mesquita Pompermaier \\ Universidade Federal de São Carlos, \\ São Carlos-SP, Brazil \\ Débora de Hollanda Souza \\ Universidade Federal de São Carlos, \\ São Carlos-SP, Brazil
}

\begin{abstract}
The present work examined aggressive behavior in a sample of children attending a child daycare center in relation to their teachers' behaviors and the types of activities proposed by them. Four teachers and their respective students were observed for an average of six sessions, during which they performed activities, which could be free (without instruction) or guided. The most frequent behaviors were pushing/pulling, fighting over objects/taking an object from someone else, and kicking/throwing objects, with $77.61 \%$ of the aggressive behavior occurring during the free activities. An association between free activities and aggressive behavior was found. The categories kicking/throwing, fighting over objects/taking an object from someone else and slapping the face were associated with free activity. These results indicate the need for more attention directed toward children's free activities, providing them with adequate space for play and diverse opportunities for exploration and object manipulation.
\end{abstract}

Keywords: aggressiveness, early childhood education, teacher-student interaction

\section{Comportamento Agressivo de Crianças em um Centro de Educação Infantil}

\begin{abstract}
Resumo: O presente trabalho examinou, em uma amostra de crianças de uma instituição de educação infantil, a relação entre comportamentos agressivos e os tipos de atividade propostos pelas educadoras. Quatro educadoras e seus respectivos alunos foram observados, em média, por seis sessões, durante as quais realizavam atividades que podiam ser livres (sem instrução) ou dirigidas. Os comportamentos mais frequentes foram os de puxar/empurrar, disputar/tirar objeto do outro e chutar/jogar objetos, sendo que $77,61 \%$ das ocorrências de comportamento agressivo foram observadas nas atividades livres. Houve associação entre as atividades livres e comportamentos agressivos. As categorias chutar/jogar objetos, disputar/tirar objetos dos outros e tapas no rosto foram as que apresentaram associação com a atividade livre. Esses resultados apontam a necessidade de se dispensar maior atenção às atividades livres das crianças, propiciando-lhes espaço adequado para o brincar e oportunidades variadas de exploração e manuseio de objetos.
\end{abstract}

Palavras-chave: agressividade, educação infantil, interação professor-aluno

\section{Comportamiento Agresivo de Niños en una Guardería}

\begin{abstract}
Resumen: El presente trabajo examinó comportamiento agresivo en una muestra de niños que frecuentan una guardería en relación a conductas de sus maestros, así como los tipos de actividades propuestas por ellos. Observamos cuatro profesores y sus respectivos estudiantes, en promedio seis sesiones durante las cuales se realizaron actividades, que podrían ser libres (sin instrucción) o guiadas. Los comportamientos más frecuentes fueran empujar/halar, disputar objetos/tomar objeto de otra persona, y patadas/tirar objetos, con $77,61 \%$ de la conducta agresiva ocurriendo durante actividades libres. Una asociación entre actividades libres y comportamiento agresivo fue detectada. Las categorías patadas/tirar, disputar objetos/tomar objeto de otra persona y bofetadas en la cara se asociaron con la actividad libre. Estos resultados apuntan a la necesidad de mejor atención a las actividades libres en la educación infantil, así como espacio adecuado y material para exploración y juego.
\end{abstract}

Palabras clave: agresividad, crianza del niño, interacción profesor-estudiante

\footnotetext{
1 This paper is based on the first author's bachelor's thesis (Psychology Undergraduate Program, Universidade Federal de São Carlos), under the supervision of the third author.

Support: During preparation of this manuscript, the fourth author was funded by Instituto Nacional de Ciência e Tecnologia sobre Comportamento, Cognição e Ensino (INCT-ECCE), which is supported by the National Council for Scientific and Technological Development (CNPq Grant \# 573972/2008-7), and by the São Paulo Research Foundation (FAPESP Grant \# 08/57705-8).

${ }^{2}$ Correspondence address:

Sidnei Rinaldo Priolo Filho. Universidade Federal de São Carlos, Programa de Pós-Graduação em Psicologia. Rodovia Washington Luís, Km 235, s/n, Jardim Guanabara. CEP 13565-905. São Carlos-SP, Brazil. E-mail: sdpriolo@gmail.com
}

The number of national and international studies on aggressive behavior and violence has increased exponentially in recent years. This growth reflects a tireless search by psychologists, educators and health professionals to understand violence as a phenomenon, as well as their investigation of its nature and origins and the most adequate methods to attenuate, prevent and even eliminate these behaviors from social life (Bandeira \& Hutz, 2012; Borsa, Souza, \& Bandeira, 2011; Hanish, Sallquist, DiDonato, Fabes, \& Martin, 2012; Liu, Lewis, \& Evans, 2013; Vieira, Mendes, \& Guimarães, 2010; Williams \& Araújo, 2010). 
In addition to efforts made to increase scientific production on aggressiveness, there is also a growing concern from many sectors of the population related to the prevention of violence in different social contexts. However, despite important advances in research on aggressive behavior in the family and school environments (McCartney et al., 2010; Souza \& Castro, 2008), aggressive behaviors in the context of early childhood education have not been investigated as frequently as should have been the case in recent years. The growing number of children attending child daycare centers in the country (Finkelhor, 2008; Monks, 2011; Pellegrini et al., 2011) and in particular, the observation that such events in very young children are not being treated as a form of violence (Finkelhor, 2008) need to be considered. In the present work, we interpret aggressive behaviors as antagonistic interactions, considering the children's reactions, the type of activity and the antecedent and consequent events of the behaviors, as proposed by Tremblay (2008). It is important to make a distinction between the type of behavior known as Rough and Tumble Play (RTP), which is characterized by the use of behaviors involving motor activity that resembles aggressiveness (e.g., pulling, running and knocking down), but in reality, constitutes part of a context of play (DiCarlo, Baumgartner, Ota, \& Jenkins, 2015). Aggressive behaviors were identified based on criteria established by Garcia, Almeida and Gil (2013), that is, a behavior was considered aggressive when it was directed from one child to the other or directed toward objects and followed by reactions of discomfort, such as crying and verbal complaints.

Recent studies have contributed to a better understanding of changes associated with aggressive behavior in typically developing children. More specifically, longitudinal studies show that the first manifestations of aggression by a child occur, in general, between the first and second years of life and there is a peak of aggressiveness between the end of the third and beginning of the fourth year (Alink et al., 2006; Côté et al., 2007). Furthermore, in contrast to the popular belief that aggressiveness always increases with age, there is strong evidence suggesting that aggressive behavior tends to decrease with time, as children acquire self-regulation strategies during preschool and, consequently, learn to inhibit aggressiveness (Nagin \& Tremblay, 1999; Thompson \& Goodwin, 2007). Following this direction, in one longitudinal study, Nagin and Tremblay (1999) investigated the trajectory of aggressive behaviors in a sample of 1037 boys who were assessed at various moments, between 6 and 15 years of age. Participants with a high frequency of aggressive behaviors in the first years of the study (in comparison to the mean of their age group) presented a distinct developmental trajectory: these children kept showing a higher frequency of aggressive behaviors when compared to their peers during subsequent years. On the other hand, children showing moderate aggressiveness (in comparison to the mean of their age group) presented a brief decrease in the frequency of aggression.

In addition to the fact that more studies on aggression in the preschool period are needed, there is also an important gap in the literature with regard to our current knowledge of the specific situations or events that can trigger an increase in aggressive behavior, and about the gravity of its consequences
(Finkelhor, 2008). The later the intervention with aggressive children, the less powerful its efficacy, which is supported by evidence of low success rates of some programs directed toward reduction of aggressiveness in adolescents (Tremblay, 2008). As the majority of children learn to inhibit physical aggression during preschool years, this particular age is considered the best period for intervention (Finkelhor, 2008; Monks, 2011; Ormeño \& Williams, 2006; Tremblay et al., 2004).

What is most concerning, however, is that many children present risk factors for the development of aggressiveness, as well as difficulties in learning effective self-regulation strategies. For example, in the longitudinal study mentioned before, conducted with 504 families in Canada, Tremblay et al. (2004) tested children over a period of 37 months, between 5 and 42 months of age, identifying their trajectory of physical aggression during this period. These researchers showed that $58 \%$ of the children followed a rising trajectory of moderate physical aggression (in comparison to their age group) and 14\% presented a rising trajectory of high aggressiveness.

Another important contribution of the longitudinal study by Tremblay et al. (2004) was the identification of important risk factors for the development of physical aggression associated with the environment of the child, for example, poverty, mothers with a history of antisocial behavior, dysfunctional families and coercive parenting style. In addition to the contribution of different risk factors, social learning plays a fundamental role in originating and maintaining aggressive behavior (Vieira, Mendes, \& Guimarães, 2010; Widom, 2014). Being exposed to domestic violence can also contribute to an increase in aggressive responses in children (D’Affonseca \& Williams, 2003; Ormeño \& Williams, 2006), more specifically, an environment in which aggression has reinforcing consequences may increase the likelihood that the child will reproduce aggressive behaviors (D'Affonseca \& Williams, 2003). It is important to note, however, that children will not necessarily repeat their parents' pattern of behaviors, although the probability is higher (Calvete \& Orue, 2011).

These risk factors are present from early on, even before the child starts school. Thus, a child who already presents frequent aggressive behavior in preschool and has one or more of the mentioned risk factors, has a greater chance of presenting an increasing trajectory of moderate or high levels of physical aggression and not the expected decrease resulting from the acquisition of self-regulation skills. Furthermore, if there is not some type of intervention, this same child will have a higher risk of presenting school problems in the future, such as learning difficulties and dropping out from school (Lisboa \& Koller, 2001; Marinho, 1999; Train, 1997). For this reason, some authors treat child aggression as a public health issue, not only considering its future effects, but also because of the risk of possible physical harm to the children themselves when they engage in aggressive behaviors (Finkelhor, 2008; Tremblay et al., 2004).

Until the present moment, studies trying to understand aggressiveness in preschool children have primarily focused on the development of techniques or training directed toward its extinction or reduction (Ormeño \& Williams, 2006; 
Webster-Stratton, 1997). These studies, however, have not tried to understand the phenomenon in different environments, such as during the years of early childhood education, and they do not seem to consider the reality of each country (Finkelhor, 2008). Furthermore, it is important to note that significant advances in executive functioning, language and social cognition characterize the preschool period, with this consequently being an important moment for the development of self-regulation (Hrabok \& Kerns, 2010).

Following this direction, the present work aims to contribute to the field of study on aggressive behavior in young children with the hope of providing useful data for future intervention programs focused on prevention. More specifically, this study aimed to identify the types of aggressive behaviors in children attending a daycare center, as well as to examine their relationship to the type of activity proposed by the teachers.

\section{Method}

\section{Participants}

Four teachers and their respective students, attending a philanthropic child daycare center in a small town located in the state of São Paulo, participated in this study. The children were distributed in different classes according to their age group, as the institution did not have, at the time of data collection, a pedagogical project to guide this distribution. The number of children in each of the participating classes varied from 12 to 18 , totaling 60 children, 35 girls (58.33\%) and 25 boys $(41.67 \%)$. The mean age of participants was 4 years and 1 month $(S D=1.05$ years), with the age range being 2 years and 5 months to 5 years and 9 months.

The child day care center had, at the time of data collection, approximately 200 children distributed in twelve classes. The institution, according to criteria established by Centro de Políticas Sociais da Fundação Getúlio Vargas (2011), was located in a neighborhood of low-income families and was selected because it had a collaboration agreement with Universidade Federal de São Carlos. It is a philanthropic daycare center that is supported exclusively by donations, with human and financial resources being limited. Several teachers had previous experience in early childhood education, however, few had university level education. The toys available at the daycare center during activities did not belong to the children and the number of toys made available during free activities was, during the majority of sessions, less than the number of children.

\section{Instruments}

Two Sony DCR-HC21 video cameras were used, which were positioned by the experimenters in strategic places in order to best register the number of interactions involving the children or between the teacher and the children. The videos were coded and all occurrences of aggressive behavior were registered and classified using the registration protocol created by Ormeño e Williams (2006), which is directed toward obtaining the frequency of the occurrence of different categories of aggressive behaviors. The instrument presents different categories of behaviors and the judge registered the moment at which the behavior occurred (time elapsed in the session) and the type of activity taking place when the aggressive behavior occurred. Thus, the instrument provided the possibility of verifying the frequencies of aggressive behaviors, the moment at which they occurred and the type of activity (free or guided) associated with each of these behaviors.

\section{Procedure}

Data collection. After a familiarization phase with the children and teachers, the principal researcher began the data collection. The children and their respective teachers were observed for an average of six sessions (number varied from five to seven). All observation sessions lasted 30 minutes each and were conducted at different times and days of the week, so that different activities could be observed. The sessions were videotaped using two video cameras located diagonally in opposite corners of the classroom. This positioning provided the best possible angle of the room and, as a result, it was possible to capture the greatest possible number of interactions. The experimenter interacted only sporadically with the children during the data collection, given that his presence was necessary so that the video cameras remained in an adequate and safe position.

The children were observed in two distinct contexts: during activities of free play and during activities guided by the teachers (for example, the teacher presented a picture and asked the children to draw the same picture with washable paint on boards). Free play was play created by the children themselves, this being a frequently used practice in the context of the daycare center.

Data analysis. In order to obtain the frequency of the categories of aggressive behavior, the videos from both cameras were coded simultaneously and in an uninterrupted manner. The frequencies of these categories were obtained for each participating class, considering the type of activity taking place (free or guided) in each session. A second judge reviewed all observation sessions in order to verify whether the behaviors registered by the first judge did in fact occur. When there was disagreement between the two judges, the item would be excluded, however, the level of agreement between judges was $98.6 \%$ and the Kappa was 0.9 , which is considered excellent by Landis and Koch (1977). Guided activities involved one of the following procedures: (a) the teacher requested attention and explained to the children what would be done next or (b) the teacher distributed all material to be used in a given activity, which would only start when the last child received the material and the instructions had been given. Free activities were those for which there was no plan or those that were initiated by the children themselves, with no intervention or instruction from the teacher. In the same session, there could be both free and guided activities. These were categorized based on whether the teacher provided instructions or not, i.e., an activity would be considered guided when the teacher gave explicit instructions about 
how the activity should be conducted and the activity would be considered free when the teacher did not provide any instruction and allowed the children, by their own initiative, to decide what to do. During free activities, the teachers, in general, engaged in other activities that were not related to what the children were doing, for example, filling out school reports or writing notes to parents in children's notebooks, among other chores not related to the activities children were engaged in.

Data were coded and analyzed using the statistical program Statistical Package for the Social Sciences (SPSS), version 20. A paired samples $t$-test was conducted in order to test for possible differences regarding mean duration time of aggressive behaviors in the two types of activity. In order to test for an association between specific aggressive behaviors and type of activity (free or guided), considering that these variables were categorical, Fisher's exact tests were conducted $(p<.05)$.

\section{Ethical Considerations}

This study was approved by the Human Research Ethics Committee of Universidade Federal de São Carlos
(Case n. 415/2010, CAAE n. 4294.0.000.135-10). Only children whose parents signed the terms of consent were allowed to participate in the study. The four participating teachers also signed the informed consent form before data collection started.

\section{Results}

Table 1 shows the total frequencies of aggressive behaviors during free and guided activities, with the behaviors that occurred most frequently being pulling/ pushing (82), fighting over/taking an object from another child (68) and kicking/throwing objects (57). There was no register of aggressive interactions between students and the teacher in any of the sessions. During guided activities, a total of 81 manifestations of aggressive behavior occurred, with 267 during free activities; the most frequent behavior in both activities was pulling/pushing, with 61 occurrences during free activities and 21 during guided. When comparing free and guided activities, the largest differences in frequency were related to behaviors involving disputes over objects or the manifestation of frustration or anger related to that dispute: fighting over/

Table 1

Absolute and Relative Frequency (\%) of Aggressive Behaviors During Free and Guided Activities

\begin{tabular}{|c|c|c|c|}
\hline Behavior & Guided Activity & Free Activity & Total \\
\hline Destroying friends' objects & $0(0 \%)$ & $1(100 \%)$ & 1 \\
\hline Punching & $0(0 \%)$ & $4(100 \%)$ & 4 \\
\hline Choking & $1(25 \%)$ & $3(75 \%)$ & 4 \\
\hline Slapping the face & $1(16.7 \%)$ & $5(83.3 \%)$ & 6 \\
\hline Kicking another child & $2(33.3 \%)$ & $4(66.6 \%)$ & 6 \\
\hline Yelling at another child & $3(50 \%)$ & $3(50 \%)$ & 6 \\
\hline Pinching & $4(50 \%)$ & $4(50 \%)$ & 8 \\
\hline Physically confronting another & $4(36.4 \%)$ & $7(63.6 \%)$ & 11 \\
\hline Hitting another child & $5(27.8 \%)$ & $13(72.2 \%)$ & 18 \\
\hline Slapping the body & $9(37.5 \%)$ & $15(62.5 \%)$ & 24 \\
\hline Hitting another with an object & $4(8.2 \%)$ & $45(91.8 \%)$ & 49 \\
\hline Kicking/Throwing objects & $4(7.0 \%)$ & $53(93 \%)$ & 57 \\
\hline Fighting over/Taking objects & $19(27.9 \%)$ & $49(72.1 \%)$ & 68 \\
\hline Pushing/Pulling another child & $21(25.6 \%)$ & $61(74.4 \%)$ & 82 \\
\hline Total & $81(23.3 \%)$ & $267(76.7 \%)$ & 348 \\
\hline
\end{tabular}

taking objects from another child, kicking/throwing objects and hitting another child with an object.

Table 2 presents the total time of observation for each activity in each class, the total number of aggressive behaviors and the interval time between occurrences of aggression. As can be observed in the table, the time teachers dedicated to guided activities was greater $(M=29888 \mathrm{~s})$ than the time dedicated to free activities $(M=13312 \mathrm{~s})$. A paired samples $t$-test revealed this difference was significant $(t(7)=$ $-5.175, p=.001)$. Nonetheless, despite the greater time spent on guided activities, 268 occurrences of aggressive behavior were observed, from a total of 348 (77.61\%), during free activities. 
Table 2

Total Time, in Seconds, of Observation During Each Activity, Total Number of Aggressive Behaviors per Activity and Mean Time, in Seconds, of Interval Time Between Aggression Occurrences

\begin{tabular}{|c|c|c|c|}
\hline Grade & Activity & Time $(s)$ & Total \\
\hline \multirow{2}{*}{ Maternal I (3 year olds) } & Free & 2400 & 29 \\
\hline & Guided & 10200 & 8 \\
\hline \multirow{2}{*}{ Maternal II (3 year olds) } & Free & 1800 & 20 \\
\hline & Guided & 7200 & 5 \\
\hline \multirow{2}{*}{ Jardim I (4 year olds) } & Free & 6743 & 175 \\
\hline & Guided & 5857 & 17 \\
\hline \multirow{2}{*}{ Jardim II (4 year olds) } & Free & 2369 & 43 \\
\hline & Guided & 6631 & 47 \\
\hline \multirow{2}{*}{ Total } & Free & 13312 & 267 \\
\hline & Guided & 29888 & 77 \\
\hline
\end{tabular}

Fisher's exact test was conducted in order to test for possible associations between type of activity (free or guided) and categories of aggressive behaviors. As can be observed in Table 3, there was a significant association between the type of activity taking place in the classroom and the children's behavior $(p<.01)$, that is, free activities were associated with aggressive behaviors in the day care center. Aggressive behaviors occurred in 38\% of free activities and in $16 \%$ of guided activities, with this difference being significant.

Table 3

Absolute and Relative Frequency (\%) of Sessions During Which There Was Manifestation (or Not) of Aggressive Behavior

\begin{tabular}{|c|c|c|c|}
\hline \multirow{2}{*}{ Activities } & \multicolumn{2}{|c|}{ Aggressive actions (in general) } & \multirow{2}{*}{$p$-value } \\
\hline & Did Not Occur & Occurred & \\
\hline Guided & $229(84 \%)$ & $44(16 \%)$ & \multirow{2}{*}{$<.01$} \\
\hline Free & $104(62 \%)$ & $65(38 \%)$ & \\
\hline
\end{tabular}

Finally, Fisher's test was conducted in order to test for a possible association between activity type (free or guided) and the different types of aggressive behavior, as presented in Table 4. The categories kicking/throwing objects, fighting over/taking objects from other children and slapping the face occurred with a significantly greater frequency during free play in comparison to guided activities.

Table 4

Percentage of Occurrence of Each Class of Aggressive Behavior per Type of Activity

\begin{tabular}{|c|c|c|c|}
\hline Aggressive Behavior & Free Activity & Guided Activity & $p$-value \\
\hline Hitting another child & $46.2 \%$ & $14.6 \%$ & .06 \\
\hline Hitting another with an object & $46.2 \%$ & $14.3 \%$ & .06 \\
\hline Pinching & $15.4 \%$ & $14.3 \%$ & .99 \\
\hline Kicking & $15.4 \%$ & $4.8 \%$ & .54 \\
\hline Kicking/Throwing objects & $53.8 \%$ & $9.5 \%$ & $.01 *$ \\
\hline Physically confronting another & $31.8 \%$ & $14.3 \%$ & .39 \\
\hline Punching & $15.4 \%$ & $0 \%$ & .14 \\
\hline Destroying friends' objects & $7.7 \%$ & $0 \%$ & .38 \\
\hline Fighting over/Taking objects & $84.6 \%$ & $38.1 \%$ & $.01^{*}$ \\
\hline Yelling at another child & $15.4 \%$ & $14.3 \%$ & .99 \\
\hline Pulling/Pushing another child & $84.6 \%$ & $57.1 \%$ & .14 \\
\hline Slaps on the face & $23.1 \%$ & $9.5 \%$ & $.02 *$ \\
\hline Slaps on the body & $61.5 \%$ & $19 \%$ & .34 \\
\hline
\end{tabular}

*Values less than $p<.05$ suggest an association between variables. 


\section{Discussion}

Although the present study was conducted with children only in the context of classroom activity in an early childhood education institution, our data revealed important associations between aggressive behavior and the type of activity proposed by the teacher.

Firstly, data analysis revealed a clear association between the type of activity being conducted and the frequency of aggressive behaviors. More specifically, the children engaged in aggressive behavior more frequently during free activities. Additionally, the teachers needed to intervene in order to resolve conflicts with a higher frequency during free play. One possible explanation for this association is related to the contingencies at work in the two situations: during free play, there was no guidance or instruction from the teachers, whereas during the planned activities, children were instructed by teachers to emit specific behaviors.

Although the total time of interaction between teacher and children in the two activities was not recorded, there may be an important difference in the amounts of attention given to the children by the teachers in the two situations. The very nature of free activity (play constructed by children themselves) may induce greater interaction between children and less between children and the teacher. It is important to note, however, that the mediation of the teacher/adult during free activities is essential so that child-child interactions can effectively become an opportunity for the development of prosocial behaviors and not for the emergence of aggressive responses. Future studies should investigate, therefore, possible effects of time of interaction and monitoring in each activity and, in particular, they should examine further the behaviors of the teachers (antecedents and consequents of the child's aggressive response) in the two types of activity (free and guided).

It is also important to remember that the reduction of close monitoring during free activities may lead to a decrease in the number of opportunities to provide consequences for children's behaviors. In this study, we found that during free activities the children were positively reinforced many times for their aggressive behavior (e.g., getting the desired toy, pushing away the child with whom they were fighting for an object), without any kind of consequence that could reduce the frequency of this group of behaviors. For example, the teacher could introduce alternative reparative behaviors, such as returning the desired toy to the upset child or providing a model of desirable behavior when disagreements occur.

Future studies should investigate the effects of planning activities for children, not only during the implementation of pedagogical activities in the classroom, but also during free or recreational periods. In the same direction, future research should investigate whether greater engagement and more monitoring/supervision from teachers during free activities could contribute to a decrease in the number of aggressive episodes in the daycare center.

It is important to note that participants' mean age was 4 years and 1 month, and the literature has shown that children between 2 and 4 years of age present a higher frequency of aggressive behaviors when compared to younger children, between 0 and 2 years (Alink et al., 2006; Côté et al., 2007). Conversely, from the age of 4 , it is possible to notice a decline in the number of aggressive events, mainly due to advances in self-regulation, associated, in turn, to the development of executive functioning and social cognition, typical of this age. In other words, as the children of the present study had a mean age of only 4 years, it is possible that they may have presented an even higher frequency of aggressive responses, as they had not yet acquired effective self-control skills. Prior to this occurring, it is possible that teachers will still encounter difficulties, corroborated by the data of Tremblay et al. (2004), which suggests an increase in the frequency of aggressive behaviors in more than $70 \%$ of children throughout the second and third years of life.

Our results are in agreement with previous findings on the incidence of bullying and aggressive behavior in young children attending childcare centers (Smith, 2011; Vlachou, Andreou, Botsoglou, \& Didaskalou, 2011). For example, Craig, Pepler, and Atlas (2000) found that the incidence of aggressive behavior and the duration of aggression are higher in the playground than in the classroom environment. As in the free activities observed in the present study, the playground is a context in which there is less supervision of children and where the activities are less structured. Other studies have contributed with the design of instruments and with teacher training in order to prevent and fight bullying in environments where supervision is less than adequate, such as the playground or the cafeteria (Leff, Power, Costigan, \& Manz, 2003).

Secondly, the results of the present study suggest that one of the most frequent types of aggressive behavior during free activities is that involving fighting over objects, which is consistent with data from Garcia, Almeida and Gil (2013). Previous studies suggest that the majority of conflicts involving young children revolve around toys (Hay, Hurst, Waters, \& Chadwick, 2011), however, the results of this study suggest that these conflicts are more frequent during free play. Recent studies have shown that peer conflict in childcare centers occurs less frequently when there is a previous determination of the ownership of the toys. More specifically, conflict is accentuated when children are in a toy room, where nobody knows who the owner of each toy is (Ross \& Friedman, 2011).

With regard to the toys available in the child daycare center, all were manufactured and of small size, which, according to Garcia, Almeida and Gil (2013), is a variable that plays an important role in children's antagonistic behaviors. Therefore, conflicts about the more desirable toys, such as pushing and pulling to keep children who want the same toy at a distance, become frequent. Thus, there were a greater number of behaviors related to conflict over objects during free activities, as shown in Table 1. During guided activities, however, the amount of materials and toys was adequate to serve the needs of all children. It is possible, therefore, that this difference in the number of toys available contributed to the increased conflict over objects during free activities. At the same time, the very nature of guided activity may result in an encouragement for cooperation and other prosocial behaviors in children (e.g., a painting session during which children can share the colored 
pencil case). Teachers' reinforcement of desirable behaviors during guided activities, greater availability of materials and closer supervision by teachers may thus have helped to inhibit conflict over objects in this condition.

Another promising line of research would be to analyze children's prosocial behaviors during free activities, given that these activities seem to contribute to the process of social learning, in particular, by encouraging collaboration, rule following, empathy, self-regulation or self-control (Zigler \& Bishop-Josef, 2006). As a result, it would be possible to examine whether free activities can also provide a good context for non-aggressive behavior in young children attending childcare centers.

In summary, aggression is a multifactorial behavior (Tremblay, 2008), which can cause physical and psychological damage to children in the short, medium and long-term (Finkelhor, 2008). At the same time, it represents a stress factor for teachers who need to solve the problems resulting from aggression episodes (e.g., helping the child victim, dealing with parents' reactions, notifying the directors/ coordinators of the institution).

Our results suggest that during free activities teachers do not mediate many interactions between children and, consequently, they are not able to inhibit the occurrence of various aggressive behaviors. Furthermore, if the teacher is not aware of the occurrence of an aggressive interaction, he/she will not be able to implement the appropriate consequences.

There is a clear and urgent need, therefore, for a deeper discussion of how daycare centers can contribute to the control and prevention of aggressive behavior. Training and guidance work directed toward the monitoring and regulation of aggressive behavior in young children is still very limited (Finkelhor, 2008).

As revealed by the literature of the area, it is during the preschool years that children acquire several selfregulation skills (Nagin \& Tremblay, 1999), with teachers playing a particularly important role in this developmental process. For example, when they talk about feelings, teach strategies for the regulation of emotions and when they reinforce prosocial behaviors, teachers can contribute more effectively to the development of children's emotional competence and, consequently, to the control and prevention of aggression (Denham et al., 2003). Furthermore, the planning of pedagogical actions in early childhood education should consider the differences between the contingencies of free and guided activities, as shown in the present study; in particular, the need for closer monitoring of children and provision of an adequate amount of materials and toys for the children, thus avoiding an increase in conflict over objects.

It is important to note that one limitation of the present study is the fact that our data is representative of an institution, which can be characterized by offering less than ideal service (e.g., high number of children in each classroom, teachers with little formal training, limited number of toys available to children). It is possible that, in childcare centers with more human and material resources, the differences found between these two types of activities would be less pronounced. A second limitation of the present study is that other variables that could be associated with aggressive behavior were not investigated, such as the level of teachers' formal training, quality and quantity of available toys, time spent by teachers with children during the free and guided activities and conflict resolution in the classroom.

Despite the increasing interest from different researchers in the development of aggression, our knowledge of aggressive behavior in preschool children is still limited (Monks, 2011). The present study aimed, therefore, to contribute to our current understanding of the phenomenon and of the possible variables controlling aggressive behaviors in young children in the context of Brazilian early childhood education.

\section{References}

Alink, L. R. A., Mesman, J., Van Zeijl, J., Stolk, M. N., Juffer, F., Koot, H. M., . . Van Ijzendoorn, M. H. (2006). The early childhood aggression curve: Development of physical aggression in 10- to 50-month-old children. Child Development, 77(4), 954-966. doi:10.1111/j.14678624.2006.00912.x

Bandeira, C. M., \& Hutz, C. S. (2012). Bullying: Prevalência, implicações e diferenças entre os gêneros [Bullying: Prevalence, implications and gender diferences]. Psicologia Escolar e Educacional, 16(1), 35-44. doi:10.1590/S1413-85572012000100004

Borsa, J. C., Souza, D. S., \& Bandeira, D. R. (2011). Prevalência dos problemas de comportamento em uma amostra de crianças do Rio Grande do Sul [Prevalence of behavior problems in a sample of children from Rio Grande do Sul]. Psicologia: Teoria e Prática, 13(2), 1529.

Calvete, E., \& Orue, I. (2011). The impact of violence exposure on aggressive behavior through social information processing in adolescents. American Journal of Orthopsychiatry, 81(1), 38-50. doi:10.1111/j.19390025.2010.01070.x

Côté, S. M., Boivin, M., Nagin, D. S., Japel, C., Xu, Q., Zoccolillo, M., . . . Tremblay, R. E. (2007). The role of maternal education and nonmaternal care services in the prevention of children's physical aggression problems. Archives General of Psychiatry, 64(11), 1305-1312. doi:10.1001/archpsyc.64.11.1305

Craig, W. M., Pepler, D., \& Atlas, R. (2000). Observations of bullying in the playground and in the classroom. School Psychology International, 21(1), 22-36. doi:10.1177/0143034300211002

D'Affonseca, S. M., \& Williams, L. C. A. (2003). Clubinho: Intervenção psicoterapêutica com crianças vítimas de violência física intrafamiliar [Kid's club: Group intervention with children at risk or victims of child abuse]. Temas Sobre Desenvolvimento, 12(67), 33-43.

Denham, S. A., Blair, K. A., DeMulder, E., Levitas, J., Sawyer, K., Auerbach-Major, S., \& Queenan, P. (2003). Preschool emotional competence: Pathway to social competence? Child Development, 74(1), 238-256. doi:10.1111/14678624.00533 
DiCarlo, C. F., Baumgartner, J., Ota, C., \& Jenkins, C. (2015). Preschool teachers' perceptions of rough and tumble play vs. aggression in preschool-aged boys. Early Child Development and Care, 185(5), 779-790. doi:10.1080/03 004430.2014 .957692

Finkelhor, D. (2008). Childhood victimization: Violence, crime and abuse in the lives of young people. New York, NY: Oxford University Press.

Fundação Getúlio Vargas. (2011). Desigualdade de renda na década [Income inequality in the decade]. Rio de Janeiro, RJ: Centro de Políticas Sociais.

Garcia, L. T., Almeida, N. V. F., \& Gil, M. S. A. (2013). Conflitos e agressões entre bebês e diferentes atributos de brinquedos: Um estudo experimental [Conflicts and aggression among infants and different attributes of toys: An experimental study.] Interação em Psicologia, 17(1), 27-36. doi:10.5380/psi.v17i1.19417

Hanish, L. D., Sallquist, J., DiDonato, M., Fabes, R. A., \& Martin, C. L. (2012). Aggression by whom-aggression toward whom: Behavioral predictors of same- and othergender aggression in early childhood. Developmental Psychology, 48(5), 1450-1462. doi:10.1037/a0027510

Hay, D. F., Hurst, S.-L., Waters, C. S., \& Chadwick, A. (2011). Infants' use of force to defend toys: The origins of instrumental aggression. Infancy, 16(5), 471-489. doi:10.1111/j.1532-7078.2011.00069.x

Hrabok, M., \& Kerns, K. A. (2010). The development of self-regulation: A neuropsychological perspective. In B. W. Sokol, U. Müller, J. I. M. Carpendale, A. R. Young, \& G. Iarocci (Eds.), Self and social regulation: Social interaction and the development of social understanding and executive functions (pp. 129-154). New York, NY: Oxford University Press.

Landis, J. R., \& Koch, G. G. (1977). The measurement of observer agreement for categorical data. Biometrics, 33(1), 159-174. doi:10.2307/2529310

Leff, S. S., Power, T. J., Costigan, T. E., \& Manz, P. H. (2003). Assessing the climate of the playground and lunchroom: Implications for bullying prevention programming. School Psychology Review, 32(3), 418-430.

Lisboa, C. S. M., \& Koller, S. H. (2001). Construção e validação de conteúdo de uma escala de percepção, por professores, dos comportamentos agressivos de crianças na escola [Construction and content's validation of the teacher's perception scale of school children aggressive behavior]. Psicologia em Estudo (Maringá), 6(1), 59-69. doi:10.1590/S1413-73722001000100008

Liu, J., Lewis, G., \& Evans, L. (2013). Understanding aggressive behaviour across the lifespan. Journal of Psychiatric and Mental Health Nursing, 20(2), 156-168. doi:10.1111/j.1365-2850.2012.01902.x

Marinho, M. L. (1999). Comportamento infantil antissocial: Programa de intervenção junto à família [Antisocial child behavior: Intervention program for the family]. In R. R. Kerbauy \& R. C. Wieleska (Eds.), Sobre comportamento e cognição: Psicologia comportamental e cognitiva da reflexão teórica a diversidade na aplicação [On behavior and cognition: Behavioral and cognitive psychology from theoretical reflection to diversity in practice] (Vol. 4, pp. 207-215). Santo André, SP: ESETEC.

McCartney, K., Burchinal, M., Clarke-Stewart, A., Bub, K. L., Owen, M. T., \& Belsky, J. (2010). Testing a series of causal propositions relating time in child care to children's externalizing behavior. Developmental Psychology, 46(1), 1-17. doi:10.1037/a0017886

Monks, C. P. (2011). Peer-victimisation in preschool. In C. P. Monks \& I. Coyne (Eds.), Bullying in different contexts (pp. 12-35). New York, NY: Cambridge University Press.

Nagin, D., \& Tremblay, R. E. (1999). Trajectories of boys' physical aggression, opposition, and hyperactivity on the path to physically violent and nonviolent juvenile delinquency. Child Development, 70(5), 1181-1196. doi:10.1111/1467-8624.00086

Ormeño, G. I. R., \& Williams, L. C. A. (2006). Intervenção precoce com crianças agressivas: Suporte à família e à escola [Early interventions with aggressive children: Family and school support]. In H. J. Guilhardi \& N. C. Aguirre (Eds.), Sobre comportamento e cognição [On behavior and cognition] (Vol. 17, pp. 169-182). Santo André, SP: ESETEC.

Pellegrini, A. D., Bohn-Gettler, C. M., Dupuis, D., Hickey, M., Roseth, C., \& Solberg, D. (2011). An empirical examination of sex differences in scoring preschool children's aggression. Journal of Experimental Child Psychology, 109(2), 232-238. doi:10.1016/j. jecp.2010.11.003

Ross, H., \& Friedman, O. (2011). Origins of ownership of property. New Directions for Child and Adolescent Development, 2011(132), 1-103.

Smith, P. K. (2011). Bullying in schools: Thirty years of research. In C. P. Monks \& I. Coyne (Eds.), Bullying in different contexts (pp. 36-60). New York, NY: Cambridge University Press.

Souza, M. A., \& Castro, R. E. F. (2008). Agressividade infantil no ambiente escolar: Concepções e atitudes do professor [Children's aggressiveness at school: Teacher's conceptions and atitudes]. Psicologia em Estudo, 13(4), 837-845. doi:10.1590/S1413-73722008000400022

Thompson, R. A., \& Goodwin, R. (2007). Taming the tempest in the teapot: Emotion regulation in toddlers. In C. A. Brownell \& C. B. Kopp (Eds.), Socioemotional development in the toddler years: Transitions and transformations (pp. 320-341). New York, NY: Guilford.

Train, A. (1997). Ajudando a criança agressiva: Como lidar com crianças dificeis [Helping the aggressive child: How to work with difficult children] (L. Reily, Trans.). Campinas, SP: Papirus.

Tremblay, R. E. (2008). Understanding development and prevention of chronic physical aggression: Towards experimental epigenetic studies. Philosophical Transactions of the Royal Society of London. Series B, Biological Sciences, 363(1503), 2613-2622. doi:10.1098/ rstb.2008.0030

Tremblay, R. E., Nagin, D. S., Seguin, J. R., Zoccolillo, M., 
Zelazo, P. D., Boivin, M., . . . Japel, C. (2004). Physical aggression during early childhood: Trajectories and predictors. Pediatrics, 114(1), e43-50.

Vieira, T. M., Mendes, F. D. C., \& Guimarães, L. C. (2010). Aprendizagem social e comportamentos agressivo e lúdico de meninos pré-escolares [Social learning and aggressive and playful behaviors of pre-school boys]. Psicologia: Reflexão e Crítica, 23(3), 544-553. doi:10.1590/S010279722010000300015

Vlachou, M., Andreou, E., Botsoglou, K., \& Didaskalou, E. (2011). Bully/victim problems among preschool children: A review of current research evidence. Educational Psychology Review, 23(3), 329-358. doi:10.1007/s10648011-9153-Z

Webster-Stratton, C. (1997). Early intervention for families of preschool children with conduct problems. In M. J. Guralnick (Ed.), The effectiveness of early intervention (pp. 429-454). Baltimore, MD: Paul H. Brookes.

Widom, C. S. (2014). Varieties of violent behavior. Criminology, 52(3), 313-344. doi:10.1111/17459125.12046

Williams, L. C. A., \& Araújo, E. A. C. (2010). Um número especial da revista Temas em Psicologia para enfrentamento da violência [A special number of the Journal Trends in Psychology on coping with violence]. Temas em Psicologia, 18(1), 7-10.

Zigler, E. F., \& Bishop-Josef, S. J. (2006). The cognitive child versus the whole child: Lessons from 40 years of head start. In D. G. Singer, R. M. Golinkoff, \& K. Hirsh-Pasek. Play = learning: How play motivates and enhances children's cognitive and social-emotional growth (pp. 1535). New York, NY: Oxford University Press.

Sidnei Rinaldo Priolo Filho is a Ph.D. candidate in the Graduate Program in Psychology at Universidade Federal de São Carlos.

Henrique Mesquita Pompermaier is a Ph.D. candidate in the Graduate Program in Psychology at Universidade Federal de São Carlos.

Nancy Vinagre Fonseca de Almeida is a Professor at Universidade Federal de São Carlos.

Débora de Hollanda Souza is an Associate Professor at Universidade Federal de São Carlos.

Received: Dec. 9, 2014

1st Revision: Apr. 30, 2015

2nd Revision: Nov. 20, 2015

Approved: Dec. 4, 2015

How to cite this article:

Priolo Filho, S. R., Pompermaier, H. M., Almeida, N. V. F., \& Souza, D. H. (2016). Aggressive behavior of children in a daycare center. Paidéia (Ribeirão Preto), 26(64), 235-243. doi:10.1590/1982-43272664201611 